Sekelyk R., PhD, Head of Cardiac surgery department, https://orcid.org/0000-0001-9951-827X

Kozhokar D., Pediatric surgeon, Cardiac surgery department, https://orcid.org/0000-0002-3579-8732

Yusifli I., Surgeon, Cardiac surgery department, https://orcid.org/0000-0002-6787-6897

Tammo R., PhD, Radiologist, Radiology department, https://orcid.org/0000-0001-7506-9449

Yemets I., MD, PhD, professor, Cardiovascular surgeon, Cardiac surgery department, https://orcid.org/0000-00021893-0164

Ukrainian Children’s Cardiac Center, Kyiv, Ukraine

\title{
Primary Closure of a Subtotal Sternal Cleft in a 7-Day-Old Neonate
}

\begin{abstract}
Sternal cleft is a rare congenital abnormality that results from incomplete fusion of the two lateral mesodermal sternal bars. It is generally accepted that primary repair in the neonatal period is the best treatment option. However, significant distance between the sternal bars can be challenging because of cardiac compression.

The aim. We report a case of a 7-day-old neonate with a subtotal sternal cleft successfully managed by direct closure.

Material and methods. A full-term male neonate weighing $3 \mathrm{~kg}$ was referred to our clinic for evaluation of a chest wall defect. The chest X-ray and computed tomography were performed to evaluate the malformation.

Results. Surgery was performed at the age of 7 days. Postoperative period was uneventful. The patient was discharged on the postoperative day 21. The first postoperative checkup after 3 months showed satisfactory cosmetic results and normal respiratory movements.
\end{abstract}

Conclusion. Despite the significant diastasis between sternal bars, primary direct closure of the sternal cleft can be safely performed in neonates.

Keywords: chest, chest wall, sternum, wound healing.

Introduction. Sternal cleft (SC) is a rare congenital abnormality which accounts for $0.15 \%$ of chest wall malformations [1]. The two lateral mesodermal sternal bars have to be fused by the eighth week of gestation but in patients with SC this process is broken. There are four main types

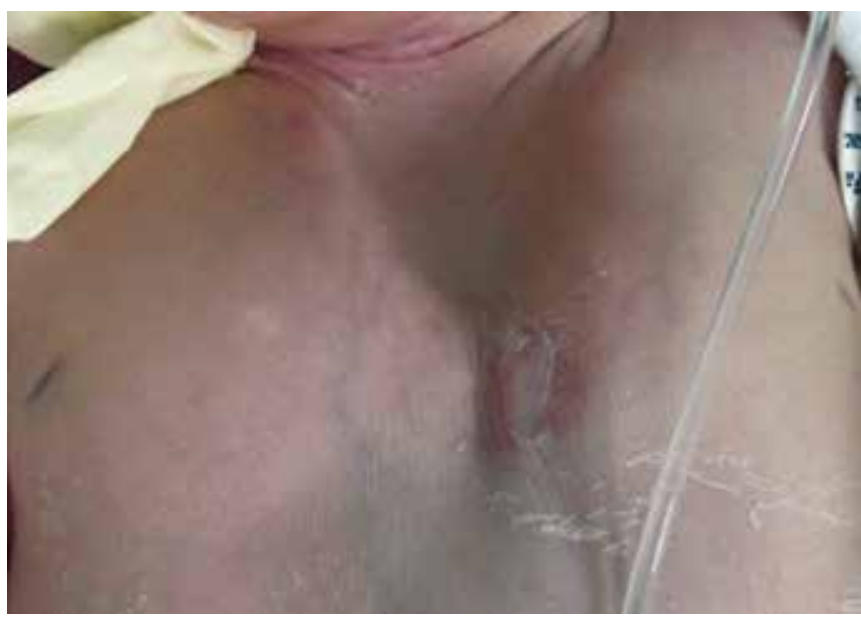

Fig. 1. Preoperative view of the defect. of this anomaly: superior, inferior, subtotal, and total cleft of the sternum [2]. We present a case of a subtotal SC diagnosed and successfully treated in a newborn.

Patients and methods. A full-term male neonate weighing $3 \mathrm{~kg}$ was referred to our clinic for evaluation of

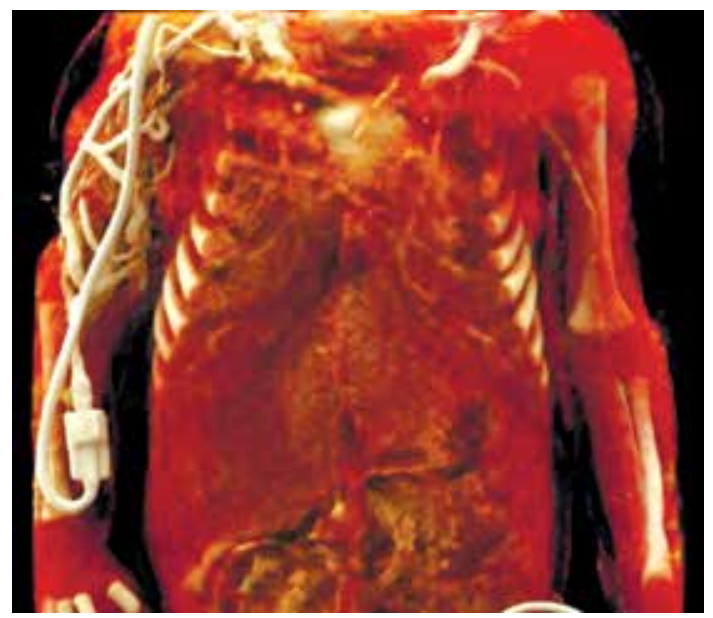

Fig. 2. Three-dimensional computed tomography scan showing the absence of the ossification center over the sternal area. 


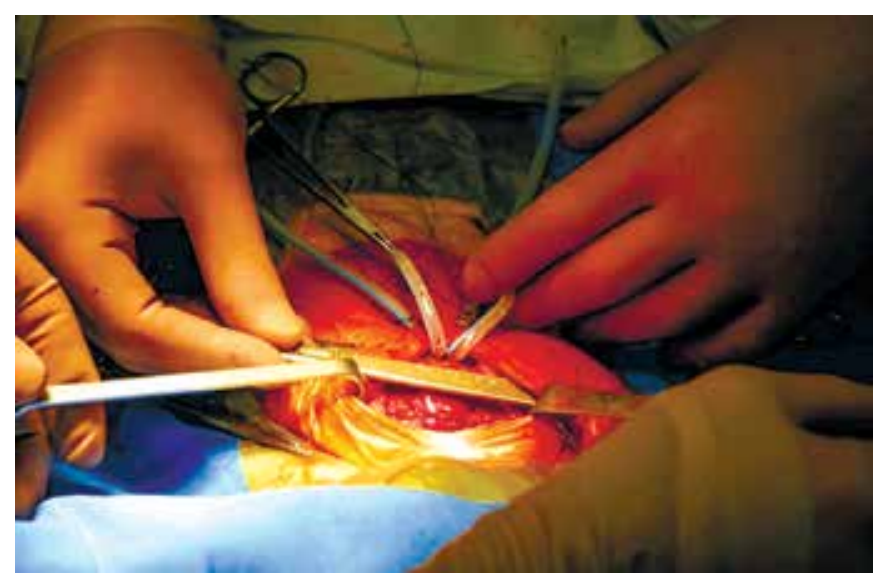

Fig. 3. Distance between the sternal bars

a chest wall defect. Examination revealed U-shaped defect in the central part of the chest wall covered by the skin (Fig. 1).

The beating heart was visible through the skin. The chest X-ray and computed tomography revealed SC with no ossification center over the sternal area (Fig. 2).

Echocardiography ruled out intracardiac defects. Surgery was performed at the age of 7 days. An upper midline incision was made over the defect. The subcutaneous tissue was densely adjoined to the pericardium. The skin, subcutaneous tissue and superficial fascia were separated from the pericardium.

Thymectomy was performed to increase the capacity of the mediastinal cavity. The distance between the sternal bars was $5 \mathrm{~cm}$ (Fig. 3).

The inferior sternal bar was divided with subsequent mobilization of the sternal edges from both sides. In addition, U-shaped defect was converted to a ' $\mathrm{V}$ ' by a careful wedge osteotomy in the xiphoid region. The two sternal bars were approximated by multiple intercostal PDS (polydioxanone) sutures which were pulled together but not tied (Fig. 4).

Heart rate, systolic blood pressure, central venous pressure, oxygen saturation, tidal volume, and airway pressure were monitored for ten minutes. All the aforementioned parameters remained stable. The PDS sutures were then tied (Fig. 5). The wound was closed in a standard manner.

Results. Post-operatively, muscle relaxants were continued during the first 24 postoperative hours in order to exclude any possibility for intra-thoracic pressure rise. Mechanical ventilation lasted 5 postoperative days for achieving good tolerance of the intrathoracic pressures. The recovery was uneventful. The patient was discharged on the postoperative day 21 . The first postoperative checkup after 3 months showed satisfactory cosmetic results and normal respiratory movements (Fig. 6).

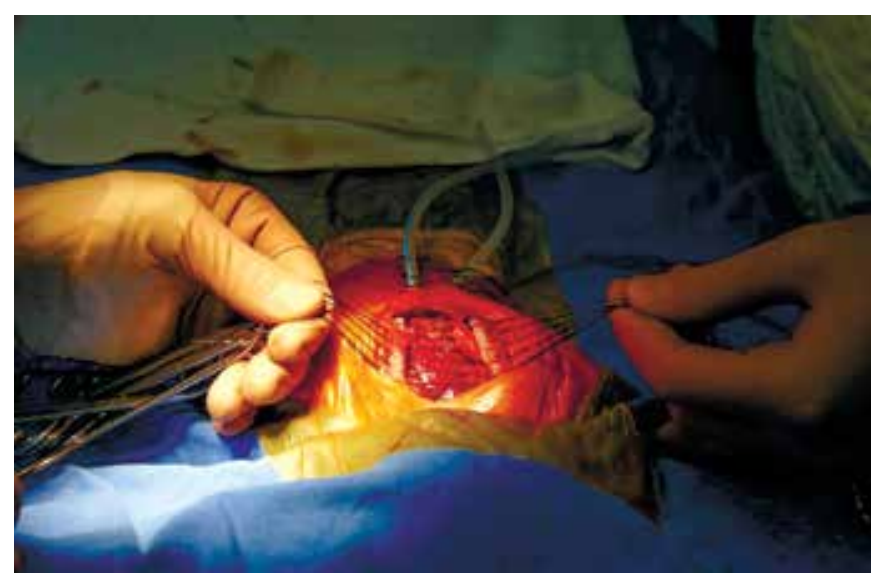

Fig. 4. Intercostal PDS sutures for approximation of the sternal bars.

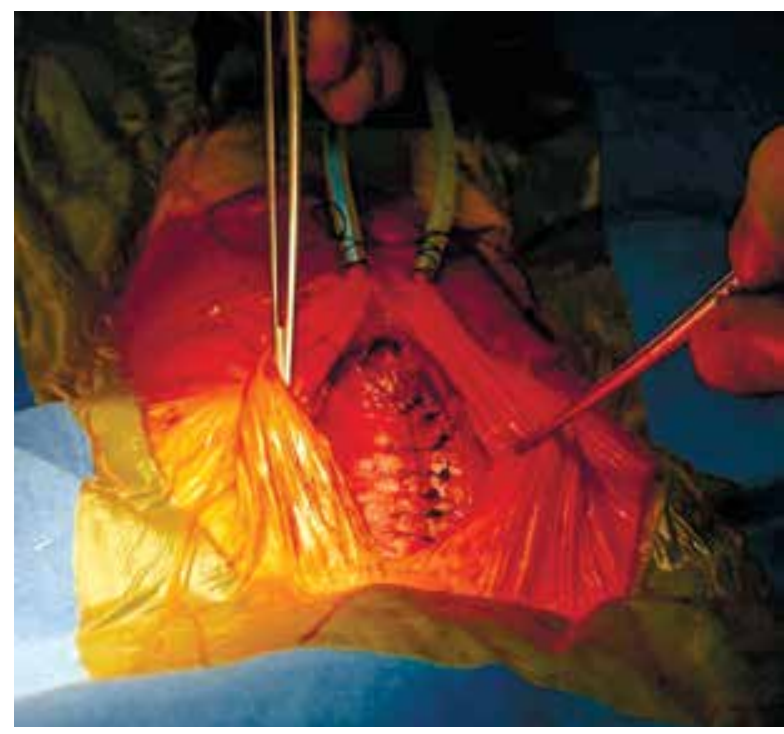

Fig. 5. Approximated sternal bars.

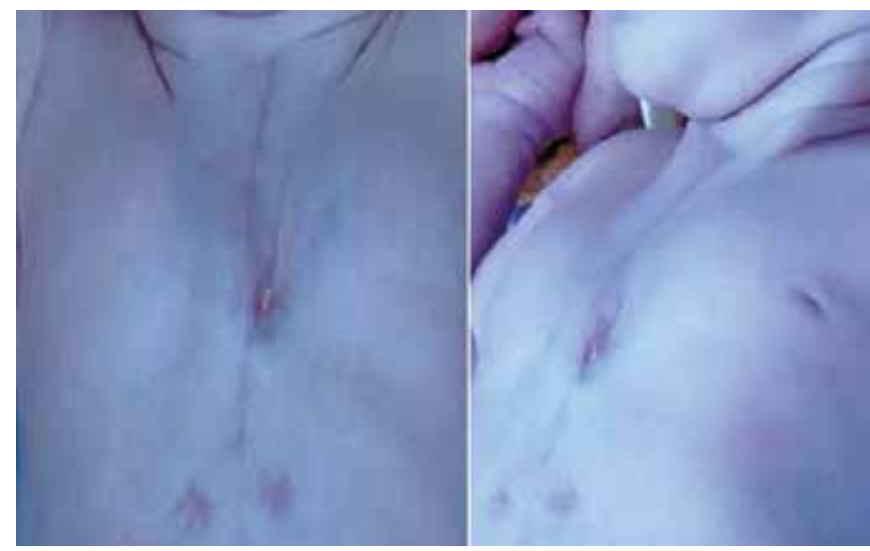

Fig. 6. Postoperative view of the patient. 
Comment. The sternal cleft is a rare congenital malformation: only about 100 cases have been previously reported in the literature [1]. Among numerous classification schemes have been described we found that the most accurate and applicable for our case was proposed by Fokin et al. [2]. In addition to partial (superior and inferior) and complete SC, the authors distinguish subtotal SC which is characterized by connection of sternal bars only at the bottom by a narrow bridge of tissue. The latter was observed in our patient.

Multiple surgical options for SC repair have been reported: primary approximation of the sternal bars, repair with autogenous tissues and prosthetic closure [4, $5,8,10]$.

It's widely accepted opinion by now that the best treatment option is a primary direct closure which should be performed in the neonatal age because the chest wall in a newborn is relatively malleable $[3,9]$.

More complex reconstruction with autogenous tissues or prosthetic closure is generally used in infants and older children. In addition, these techniques could be a method of choice in difficult cases in neonates. Ballouhey et al. managed a SC in an infant with a double osteochondroplasty flap [6]. Semlacher et al. reported a case of neonate with SC where the sternum was reconstructed with a synthetic mesh which was removed 21 days after surgery due to infection. Subsequently, the sternum was repaired using a porcine acellular dermal matrix [5].

In our case, given the significant distance between sternal bars $(5 \mathrm{~cm})$, we have considered multistage surgical repair with a gradual approximation of the sternal bars by simple suturing during each stage, as it was proposed by Baqain et al. [7], as a "theoretical approach, not yet reported". It would be an option of choice if the patient did not tolerate direct suturing.

Finally, close monitoring for 10 minutes during the intervention before the sutures tying helped to determine that direct closure is achievable without cardiovascular compromise.

Conclusion. Despite the significant diastasis between sternal bars, primary direct closure of the sternal cleft can be safely performed in neonates.

Authors' Note. Consent to publish this case report was obtained from the patient's family.

\section{References}

1. Ates MS, Duvan I, Onuk BE, Kurtoglu M. Isolated Sternal Cleft in a Patient With Coronary Artery Disease. World J Pediatr Congenit Heart Surg. 2016 Mar;7(2):238-40. https://doi.org/10.1177/2150135115589790

2. Fokin AA, Steuerwald N, Ahrens WA, Allen KE. Anatomical, histologic, and genetic characteristics of congenital chest wall deformities. Semin Thorac Cardiovasc Surg. 2009;21(1):44-57. https://doi.org/10.1053/j. semtcvs.2009.03.001

3. Torre M, Rapuzzi G, Carlucci M, Pio L, Jasonni V. Phenotypic spectrum and management of sternal cleft: literature review and presentation of a new series. Eur J Cardiothorac Surg. 2012;41(1):4-9. https://doi. org/10.1016/j.ejcts.2011.05.049

4. Yavuzer S, Kara M. Primary repair of a sternal cleft in an infant with autogenous tissues. Interact Cardiovasc Thorac Surg. 2003 Dec;2(4):541-3. https://doi.org/10.1016/ S1569-9293(03)00127-0

5. Semlacher RA, Nuri MAK. Successful management of absent sternum in an infant using porcine acellular dermal matrix. Arch Plast Surg. 2019 Apr 11;46(5):470474. https://doi.org/10.5999/aps.2018.00829

6. Ballouhey Q, Armendariz M, Vacquerie V, Marcheix PS, Berenguer D, Mouliès D, Fourcade L. Primary repair of sternal cleft with a double osteochondroplasty flap. Interact Cardiovasc Thorac Surg. 2013;17(6):1036-7. https://doi.org/10.1093/icvts/ivt380

7. Baqain EB, Lataifeh IM, Khriesat WM, Fraiwan NM, Armooti MA. Primary repair of a large incomplete sternal cleft in an asymptomatic infant with Prolene mesh. J Pediatr Surg. 2008 Oct;43(10):e39-41. https://doi.org/10.1016/j. jpedsurg.2008.05.036

8. Smith AEP, Mani A, Jones A, Jordan SJ. Surgical repair of complete congenital sternal cleft associated with pectus excavatum. The Annals of Thoracic Surgery. 2020;109(1):e51-e53. https://doi.org/10.1016/j. athoracsur.2019.04.079

9. Al-Yamani M, Lavrand F, Thambo JB, Roubertie F. Upper sternal cleft with a complex congenital heart defect: repair in a single stage. Ann Thorac Surg. 2016;101(2):760-2. https://doi.org/10.1016/j. athoracsur.2015.03.049

10. Dumitrescu A, Ryan CA, Green A. Sternal cleft malformation in a newborn. BMJ Case Rep. 2017;2017:bcr2017220237. https://doi.org/10.1136/bcr-2017-220237 


\section{Одноетапна корекція розщеплення грудини у новонародженого}

Секелик Р. І., канд. мед. наук, лікар-хірург серцево-судинний, завідувач відділення серцевої хірургії новонароджених, https://orcid.org/0000-0001-9951-827X

Кожокар Д. М., лікар-хірург дитячий відділення серцевої хірургії новонароджених, https://orcid.org/0000-0002-3579-8732

Юсіфлі Бахруз огли І., лікар-хірург відділення серцевої хірургіï, https://orcid.org/0000-0002-6787-6897

Таммо Р., канд. мед. наук, лікар-радіолог відділення радіології, https:/orcid.org/0000-0001-7506-9449

Ємець І. М., д-р мед. наук, професор, лікар-хірург серцево-судинний відділення серцевої хірургії новонароджених, httрs:// orcid.org/0000-0002-1893-0164

ДУ «Науково-практичний медичний центр дитячої кардіології та кардіохірургії МОЗ України», м. Київ, Україна

Резюме. Розщеплення грудини - це рідкісна вроджена вада розвитку грудної клітки. Незростання бластем, відомих під назвою «надгрудинної тканини», перешкоджає з'єднанню краніального кінця половинок, з яких формується грудина. Унаслідок цього утворюється повний або частковий дефект грудини.

Запропоновано чимало технік для корекції розщеплення грудини: первинний шов грудини, пластика власними тканинами та пластика грудини з використанням синтетичних матеріалів.

«Золотим стандартом» $є$ корекція в неонатальному періоді методом первинного шва, суть якого полягає у зшиванні по середній лінії рудиментів грудини після їх часткового крайового розсікання. Цю техніку застосовують у пацієнтів з незначним діастазом країв грудини (2-3 см) та в дітей раннього віку, коли грудна клітка податлива та достатньо пластична, що дозволяє з'єднати обидві половини грудини без труднощів.

При більшому діастазі методом вибору є пластика власними тканинами. Недоліком методу є необхідність агресивних маніпуляцій (розсічення м'язів, остеохондротомії та ін.), що погіршує умови загоєння рани. Використання синтетичних матеріалів у свою чергу може призводити до інфекційних ускладнень. Альтернативним підходом $є$ етапна корекція з поступовим наближенням країв грудини.

Мета роботи. У нашій роботі описано випадок одноетапної корекції субтотального розщеплення грудини у пацієнта зі значним діастазом країв методом первинного шва.

Матеріали та методи. Рентгенографія та комп'ютерна томографія були застосовані для візуалізації анатомії грудної клітки.

Результати. Хірургічне втручання було проведено на 7-у добу життя. Тимектомія та широка мобілізація країв грудини з частковим крайовим розсіканням дали змогу збільшити об'єм грудної клітки. Пробне тимчасове наближення країв грудини з моніторингом частоти серцевих скорочень, артеріального тиску, центрального венозного тиску, параметрів вентиляції протягом 10 хвилин дозволили впевнитись у безпеці одномоментної пластики значного діастазу грудини методом первинного шва. Післяопераційний період перебігав без ускладнень, тривалість госпіталізації становила 21 день.

Висновок. Незважаючи на значний діастаз між краями грудини, метод первинного шва може бути безпечно використаний у новонароджених.

Ключові слова: грудна клітка, грудна стінка, грудина, загоєння рани.

Стаття надійшла в редакцію 18.11.2020 р. 